7. Трачук В. В. Психологічна характеристика спорту як виду діяльності. URL : http://elartu.tntu.edu.ua/bitstream/lib/29707/6/ dyplom_Trachuk. pdf.

8. Фактори формування мотивації досягнення успіху. URL : http://bo0k.net/index.php?p=achapter\&bid=16404\&chapter $=$

DOI https://doi.org/10.30525/978-9934-26-146-6-3

\title{
КАТЕГОРІЯ «ДУША» В ІСПАНСЬКІЙ ПСИХОЛОГІЇ НА МЕЖІ ХІХ - ХХ СТОЛІТЬ
}

\author{
Зайченко Н. I. \\ доктор педагогічних наук, \\ професор кафедри загальної та прикладної психології \\ ПВНЗ «Інститут екології економіки і права» \\ м. Київ, Украӥна
}

Категорія «душа» - ключова категорія іспанської психології на межі XIX - XX століть. Психологія визначалася в той час як «наука про душу» i призначалася головним чином для пояснення сутності та устрою людської душі. У «Компендіумі психології, логіки й етики» (Мадрид, 1891 р.) викладача Сарагоського Інституту середньої освіти Л. Елейсальде Йзагірре (Luis Maria Eleizalde e Yzaguirre) наголошувалося: «душа - це первинна основа життя в тілесній органічній субстанції» $[1$, с. 9]; «розумна душа є субстанціональною формою людського тіла» [1, с. 138].

Зазначалося і про те, що душа - духовної природи, вона за сутністю незалежна від матерії. У «Компендіумі...» духовність душі пояснювалася таким чином. Людський розум пізнає велике розмаїття об'єктів, воно не може вражати виключно органи відчуття. Пізнання таких нематеріальних речей, як можливість, неможливість, право, обов'язок, справедливість, підвладне душі, яка функціонує незалежно від органів відчуття, яка існує віддільно від матерії. Доказом духовності душі виступає, на думку Л. Елейсальде Йзагірре, й те, що ііі унікальна здібність - воля, «господарка людських дій», $є$ «вільною», $\epsilon$ «потенцією незалежною від матерії» [1, с. 94-95].

У «Компендіумі психології, логіки і філософії моралі» (Валенсія, 1890 р.) викладача Валенсійського Інституту середньої освіти М. Поло Пейролона (Manuel Polo y Peyrolon) стверджувалося: «дух - це 
субстанція в сутності відмінна й незалежна від матерії, розумна і вільна; раціональна душа $\epsilon$ найпростіша, нематеріальна, розумна, вільна та незалежна від тіла настільки, наскільки вона реалізує свої неорганічні можливості» [2, с. 77].

Душа і тіло людини мають розумітися в єдності на трьох рівнях: a) субстанціональному рівні, оскільки людська істота може існувати тільки в єдності двох факторів - душі й тіла; коли ж людина помирає, ця єдність руйнується і душа відділяється від тіла; б) природному рівні, адже душа й тіло функціонують у взаємозв'язку; в) особистісному рівні, бо з поєднання душі і тіла формується єдина розумна істота як основа особистості [2, с. 80].

У посібнику викладача Гранадського університету Х. Еспаньї Льєдо (Jose España Lledo) «Елементи філософії» (Кордова, 1895 р.) наголошувалося, що «душа дає людині змогу відчувати, розуміти й воліти»; душа - це «субстанція нематеріальної природи», «духовна субстанція» [3, с. 168]; душа - то є «активний принцип наших почуттів, розмислів та волінь» [3, с. 161].

3-поміж властивостей душі X. Еспанья Льєдо звертав увагу на такі, як простота душі (душа істотно не розпадається на жодні елементи); безсмертність (душа не руйнується, відділяючись від тіла); духовність (душа існує незалежно від матеріі).

У книзі «Філософія. Психологія» (Мадрид, 1900 р.) Х. Еспанья Льєдо продовжив здійснювати теоретичний аналіз категорії «душа». Він доводив тези про те, що «душа людини - джерело і корінь усіх ії дій», що «душа - істинна субстанція» [4, с. 11]; обгрунтовував ідеї про недосконалість людської душі, про іiї доленосне призначення, про необхідність ï індивідуального вдосконалення протягом земного життя людини [4, с. 11-12].

$\mathrm{У}$ «Курсі зі психології, логіки й філософії моралі» (Логроньо, 1892 р.) Л. Морено Бустаманте (Luis Moreno Bustamante) акцентував увагу на тому, що «душа - то $є$ сутність усередині нас, котра відчуває, розуміє й воліє» [5, с. 17].

Властивості душі у «Курсі...» було розподілено за двома групами: 1) істотні властивості - єдність душі, ідентичність та активність; 2) другорядні - властивості, характерні саме для людської душі, наприклад, розумність іiі. Єдність душі розуміється як «відсутність частин», неподільність душі на складники. Ідентичність - це постійність душі в часовій протяжності. Активність душі - то є сила, яка спонукає людину до діяльності [5, с. 19-21].

На думку Ф. Далмау Гратакоса (Federico Dalmau у Gratacos), висловлену ним в роботі «Елементи філософії. Психологія» (Барселона, 
1912 р.), душа - «основа всіх психічних явищ, властивих людині»; душа дає змогу людській істоті відчувати, уявляти, розуміти, судити, мислити, любити, воліти тощо [6, с. 315].

На три невід'ємні істотні властивості душі - простоту, духовність та безсмертність - вказували і філософ Х. Орті Лара (Juan Manuel Orti у Lara) [7, с. 132], і педагог А. Буено (Angel Bueno) [8, с. 5].

На переконання X. Орті Лари, душу розумну (людську) слід розуміти насамперед як «субстанціональну форму тілесного» [7, с. 145], а єдність душі і тіла - як «єдність субстанціональну» [7, с. 146]. Здібності людини відчувати, розуміти, мислити, судити, воліти є душевними здібностями, $\epsilon$ проявами індивідуальної душі. Людська душа виконує свою земну місію тоді, коли вона пізнає доленосне призначення та цілковито спрямовується на його реалізацію. Основна мета, з якою особистість наділяється душею, має ірраціональний сенс: душа має привести людину до Бога. Як писав А. Буено: «така доброчинність із доброчинностей, як мир душі, або спокій свідомості, душевне самовладання, досягається єдино можливим чином - завдяки постійній роботі над добром; зрозуміло, що допомагає і веде віра в Бога, бо без цієї допомоги нічого не може людина» $[8$, с. 16].

У книзі «Антропологія або філософія людини» (Мадрид, 1915 р.) I. Дiaca (Isidoro Diaz) йшлося про те, що душа - основа трьох функцій відчуття, мислення та воління; що «вона існує в дійсності» [9, с. 216]; що душа в поєднанні з тілом утворює цілісну людську істоту. Істотними властивостями душі було визначено: «субстанціональність, єдність, простоту, нематеріальність, духовність та безсмертність» [9, с. 216].

I. Діас доводив, що душа є субстанцією, зокрема, тому що «існує сама по собі, а результати ії праці - мислення, уявлення, науки, рішення не $\epsilon$ продуктом жодного органу [тіла]» [9, с. 217]. Сдність душі проявляється в тому, що вона - одна в конкретному бутті, а ії простота - полягає в тому, що душа не має складників, не розпадається на окремі частини [9, с. 218]. Нематеріальність душі пояснювалася в «Антропології» таким чином: душа не має спроможності розширюватися, як усе матеріальне, отже, вона - нематеріальна [9, с. 220]. Духовність душі виражається в тому, що людська душа функціонує як дух і проявляється як чуття, розум та свобідне воління [9, с. 221]. Нарешті, безсмертність - це «властивість душі існувати завжди» [9, с. 221].

Іспанські мислителі на зламі століть XIX і XX стояли на позиції, що людська душа - творіння Боже. Саме Бог задумав людську істоту 3 подвійною природою - тілесною і духовною одночасно. «Людина не $\epsilon$ ні тільки дух, ні тільки душа, ні тільки матерія, а $\epsilon$ - сукупністю всіх цих 
елементів, істотно єдиних, з яких постає єдине буття, єдина субстанція та єдина особистість», - підкреслював I. Діас [9, с. 235].

На переконання іспанських філософів та психологів на межі XIX $\mathrm{XX}$ століть, душа - основа земного буття людини; саме душа вможливлює осмислене функціонування особистості в земному світі, оскільки вона прагне здійснити своє доленосне призначення. Завдяки праці душі людина пізнає навколишнє, змінює його та вдосконалюється сама. Завдяки роботі душі людина здобуває «земне щастя» та націлюється на «вічне». «Душа» - для іспанської психології на переломі століть XIX і XX - категорія основоположна. Тогочасній іспанській психологічній науці в іiі метафізичному модусі ще не під силу було відірватися від традиційної християнської догматики.

\section{Лiтература:}

1. Eleizalde e Yzaguirre L. Compendio de Psicologia, Logica y Etica. Madrid: Establecimiento Tipografico de G. Juste, 1891. 500 p.

2. Polo y Peyrolon M. Compendio de Psicologia, Logica y Filosofia moral. Valencia: Imprenta de Manuel Alufre, 1890. 280 p.

3. España Lledo J. Elementos de filosofia. Cordoba: Imprenta y Libreria del Diario de Cordoba, 1895. 240 p.

4. España Lledo J. Filosofia. Psicologia. Madrid: Libreria de Hernando y Compañia, 1900. 225 p.

5. Moreno Bustamante L. Curso de psicologia, logica y filosofia moral. Logroño: Imp. y Lib. de D. Ricardo M. Merino, 1892. 464 p.

6. Dalmau y Gratacos F. Elementos de Filosofia. Psicologia. Barcelona: Luis Gili Ed., 1912. 430 p.

7. Orti y Lara J. Curso abreviado de metafisica y filosofia natural. Vol. II. Filosofia natural. Madrid: Casa Editorial de San Francisco de Sales, $1898.200 \mathrm{p}$.

8. Bueno A. Alma. Burgos: Imp. y lib. de Hijos de Santiago Rodriguez, 1897. 33 p.

9. Diaz I. Antropologia o filosofia del hombre. Madrid: Imprenta de Candido Alonso y Compañia, 1915. 273 p. 